\title{
Growth of Native Plants on Mined Materials was not Improved by a Commercial Microbial Inoculant
}

Hongtao Zhong ( $\square$ hongtao.zhong@uwa.edu.au )

University of Western Australia https://orcid.org/0000-0003-0674-0010

Wei San Wong

Jun Zhou

https://orcid.org/0000-0001-7315-6645

Adam Cross

Hans Lambers

\section{Research Article}

Keywords: magnetite tailings, commercial microbial inoculant, plant nutrient-acquisition strategies, minesite restoration, topsoil management,

Posted Date: February 7th, 2022

DOI: https://doi.org/10.21203/rs.3.rs-1308844/v1

License: (1) (i) This work is licensed under a Creative Commons Attribution 4.0 International License.

Read Full License 


\section{Abstract}

\section{Background and aims}

Post-mining landscapes are often lacking in a self-sustaining plant community and in a functional belowground microbial community. Inappropriate management of soil can hinder ecological restoration of mine sites. However, the potential role of microbial inoculants and plant nutrient-acquisition strategies in improving mined substrates and facilitating mine-site restoration remains relatively unexplored. We tested (1) whether a commercially-available microbial inoculant was effective in restoring biological properties of mined substrates, and (2) the effect of plant nutrient-acquisition strategies on improving the chemical properties of mined substrates for the growth of native plants.

\section{Methods}

We conducted a six-month glasshouse experiment, growing six native plant species with different nutrient-acquisition strategies and adding a commercial microbial inoculant in three substrates (topsoil, magnetite tailings and a combination of both) from an iron-ore mine site in mid-west Western Australia.

\section{Results}

There was no significant improvement in plant growth by adding a commercially-sourced microbial inoculant. Soil microbial biomass carbon and nitrogen increased significantly after plant growth (main effect of species * inoculation interaction). The non-mycorrhizal disturbance-specialist plant species Maireana georgei was effective in improving hostile conditions of the tailings.

\section{Conclusions}

Our results indicate that re-vegetating stockpiled topsoil using local keystone species is a desirable practice that can improve soil biological properties and benefit mine-site restoration. Commerciallyavailable agricultural-based microbial inoculants may not be compatible for mine-site restoration using native plants, but future research using indigenous soil microbes is warranted. We recommend selecting native plant species with different nutrient-acquisition strategies and complementary traits (e.g., $\mathrm{N}$-fixing and P-mobilising) when restoring mined substrates.

\section{Introduction}

Increasing demand for mineral resources has led to ever-increasing mining footprints globally, resulting in large quantities of mined materials that often require rehabilitation or ecological restoration (AznarSánchez et al. 2019). Australia is a major producer and exporter of mineral resources, particularly iron (Fe) ore, producing about 900 million tonnes of Fe ore in 2020 (Senior et al. 2021). Significant Fe ore extraction occurs in remote areas of Western Australia, many areas of which harbour high biodiversity and high rates of endemism (Gibson et al. 2012). In Western Australia, as in many other jurisdictions in the country, there is often a legal requirement that post-mining landscapes are returned to a functioning, 
biodiverse native ecosystem comprising native plant communities through the process of ecological restoration (Stevens and Dixon 2017).

Mining operations are among the most ecologically damaging activities humans impose on ecosystems. Usually, large areas of natural vegetation have to be cleared and topsoil has to be stripped during mining operations (Roche and Mudd 2014). Although the value of topsoil for post-mining ecological restoration is widely acknowledged, including as a reservoir of seeds, soil biota and available plant macronutrients (Fowler et al. 2015), it remains common practice to stockpile stripped topsoil for long periods (months to years) because often the direct transfer of topsoil to the recipient restoration site is not feasible (Roche and Mudd 2014). Long stockpiling periods in this manner degrade the biological quality of topsoil mainly due to lack of plant carbon inputs (Zheng et al. 2019). For example, Kumaresan et al. (2017) found that long-term topsoil stockpiling virtually killed off the original microbial community. Additionally, the surface area of post-mining land is often much greater than the area cleared, resulting in a large topsoil deficit (Ghose 2001). In addition, along with the lifetime of mining operations, large quantities of mine tailings are produced. Tailings are usually very challenging for the re-colonisation of most plants due to hostile physiochemical properties, including a lack of soil physical structure, extreme $\mathrm{pH}$, low organic matter content, and absence of available nitrogen (Cross et al. 2021b). These can severely hamper the potential for successful mine-site restoration. So, it is often necessary to ameliorate the extreme physiochemical conditions of tailings while trying to re-establish the native vegetation.

To overcome these issues, first the health of stockpiled topsoil needs to be retained if freshly deposited or restored if already stockpiled (Merino-Martín et al. 2017); second, using mine tailings as a novel soilforming parent material to "eco-engineer" additional growth substrates should be considered (Santini and Banning 2016; Zhong et al. 2021). Many approaches have been proposed to facilitate and promote successful mine-site restoration, including organic amendments and biochar application (Larney and Angers 2012; Park et al. 2014), inoculation with plant growth-promoting bacteria (Padda et al. 2021), and seed-based enablement and coating technologies (Erickson et al. 2017). These approaches have the potential to improve seed germination, early plant growth and establishment, while in many cases plant root systems cannot further develop into the un-amended substrates, or early-established plant communities could not proceed with positive ecological succession (Huang et al. 2012), and therefore a self-sustaining plant community is not formed. Therefore, more innovative ways need to be trialled to improve the ecological restoration of mined substrates.

On the one hand, the biological integrity of soil, namely microbial community structure, has increasingly become a critical component for ecological restoration of degraded land (Hart et al. 2020). It is well documented that a healthy community of soil microorganisms can benefit soil aggregation and nutrient cycling, plant growth and abiotic stress tolerance (Singh et al. 2011). Potentially, application of commercially-available microbial inoculant has been proposed for mine-site restoration (Perkins and Hatfield 2016), although often such selected microorganisms also pose threats to local soil biodiversity via changing the microbial communities (Hart et al. 2017). However, the effectiveness of applying commercial microbial inoculants on improving the biological properties of mined substrates, hence 
promoting plant growth, are still unclear. On the other hand, the importance of considering resource acquisition of plants during early succession on man-made waste substrates was pointed out by Marrs and Bradshaw (1993); however, this aspect has been little studied (Cross 2021). Plant nutrient-acquisition strategies refer to different plant groups that evolved specialised belowground traits to overcome nutrient limitation, such as carboxylate exudation and/or cluster-root formation and forming symbiotic relationships with microorganisms in the rhizosphere (Lambers 2022). For example, using plant traits to screen potential nurse plant species for promoting the restoration of ecosystem functions, such as soil fertility and stress resilience, was applied in restoration of mine tailings in Spain (Navarro-Cano et al. 2018). However, what has been less investigated is whether plants with different nutrient-acquisition strategies have different effects on remediating biogeochemical properties of mined substrates, for example, alleviating extreme $\mathrm{pH}$, building up organic $\mathrm{C}$, and increasing nutrient pools. Also, the effectiveness of applying commercial microbial inoculants and their interaction with plant nutrientacquisition strategies on the remediation of mined substrates is still unclear. Therefore, in the present study, through a glasshouse trial we investigated: (1) whether the biological properties of mined substrates can be improved through applying a commercially-available microbial inoculant, and (2) whether plant species with contrasting nutrient-acquisition strategies and the interactions with microbial inoculant will affect remediation of mined substrates.

\section{Material And Methods}

\section{Study area}

Native plant species and growth substrates were sourced from a magnetite mining operation in the midwest region of Western Australia, located $400 \mathrm{~km}$ northeast of Perth. This area experiences a semi-arid Mediterranean climate with mild wet winters (mean monthly maximum $19^{\circ} \mathrm{C}$ ) and hot dry summers (mean monthly maximum $37^{\circ} \mathrm{C}$ ). The study area receives $311 \mathrm{~mm}$ annual rainfall, about $65 \%$ of which falls between May and September (winter; Australian Bureau of Meteorology, http://www.bom.gov.au/climate/data/, Station 10195). This area also experiences $2400 \mathrm{~mm}$ of potential annual evapotranspiration, leading to an annual water balance of approximately $-2100 \mathrm{~mm}$.

The mining area is located in the Yalgoo Bioregion according to the Interim Biogeographic Regionalisation for Australia (version 7; http://www.environment.gov.au/land/nrs/science/ibra). The local plant communities are typical Eremaean sclerophyll shrublands (Beard 1990). Plant communities are generally low to open woodlands, predominantly comprising shrubs or trees of Acacia spp. (e.g., A. sibina, A. ramulosa var. ramulosa), Eucalyptus spp. (e.g., E. leptopoda, E. kochii), Melaleuca leiocarpa, Allocasuarina acutivalvis, Callitris columellaris, and Hakea recurva subsp. recurva, with an understorey of shrubs, grasses and herbaceous annuals (Markey and Dillon 2008).

Natural topsoil at the study area comprises highly-weathered red earth, from stony red loamy sand to loamy clay soil (Leptic Rudosol, Orthic Tenosol or Red Kandosol, according to Australian Soil Classification) containing abundant fragments (usually 2-20 mm) of ironstone gravel (Payne et al., 
1998). All rocky material (>40 mm) and all large woody debris (branches and twigs) were removed prior to experimental use. Stockpiled topsoil used in the present study was sourced from stripped natural topsoil (top $15 \mathrm{~cm}$ ) but was stockpiled for ca. 4-5 years. Dry-stacked magnetite tailings (hereafter referred to as tailings) were generated as fine-textured (processed by high-pressure grinding to $<4 \mathrm{~mm}$ ) waste materials at the end of magnetite-ore processing. Selected physical and chemical profiles for topsoil and tailings are presented in Cross et al. (2021b), with mineralogical characteristics presented in Wu et al. (2019).

\section{Plant species selection and growth conditions}

The experiment was conducted in a glasshouse at the University of Western Australia, Perth, between May and December 2018. Six plant species native to the region were selected for the study, including Acacia ramulosa (Fabaceae), Allocasuarina acutivalvis (Casuarinaceae), Austrostipa scabra (Poaceae), Eucalyptus loxophleba (Myrtaceae), Hakea recurva (Proteaceae), and Maireana georgei

(Chenopodiaceae). These species are common components of native vegetation assemblages adjacent to the storage facility of the tailings at the study site, and represent a wide range of taxonomic and functional diversity including a variety of nutrient-acquisition strategies and symbiotic associations with soil biota (Table S1). These species were selected based on their performances in a study of 40 native plant species grow on Fe ore mine tailings (Cross et al. 2021a).

Seeds were purchased from Nindethana Seed Service Pty Ltd (Albany, Western Australia) and sown in plastic tapered square pots $(18 \mathrm{~cm} \times 18 \mathrm{~cm} \times 44 \mathrm{~cm})$ containing the experimental substrates. For $A$. ramulosa, $H$. recurva and $M$. georgei, 15 seeds were sown per pot, whereas equal weights of seeds were sown for the smaller-seeded species, $A$. acutivalvis ( $0.10 \mathrm{~g}$ per pot, $\sim 35$ seeds); $A$. scabra ( $0.10 \mathrm{~g}$ per pot, $\sim 20$ seeds); and E. loxophleba (0.02 g per pot, 100 seeds). To yield comparable biomass between species, same numbers or weights of seeds from each species were sown initially. Plants of each species were grown in three treatment substrates including capped tailings, tailings, and stockpiled topsoil with 5 replicate pots for each substrate treatment. Capped tailings pots contained about $4.8 \mathrm{~kg}$ of tailings overlain by $1.2 \mathrm{~kg}$ of mixed topsoil and tailings (1:1 w/w), so as to mimic the proposed substrate design in the mine-closure plan. Topsoil and tailings pots contained about $6 \mathrm{~kg}$ pure stockpiled topsoil and tailings, respectively.

Within each substrate treatment, half of the pots were provided with a microbial inoculum (hereafter, referred to as inoculated). Each inoculated pot was treated with $100 \mathrm{ml}$ of inoculant containing $2 \mathrm{~g}$ of a commercial freeze-dried microbial mix (Langley Fertilizers Troforte ${ }^{\circledR}$ Microbe Blend - Cropping, Sunpalm Australia Pty Ltd, Wangara, WA, Australia; Appendix 1 and 2 in Supplemental Materials), reconstituted in deionised (DI) water, at one and two months after seeds were sown. The fertilisation effect of the added inoculant can be neglected, given that it was diluted first by $100 \mathrm{ml}$ of DI water and then by $6 \mathrm{~kg}$ of substrate. Additional unseeded pots were established as controls to compare changes over time and in contrast with seeded substrates and inoculation treatment. Water content was maintained at approximately $15-20 \%$ (water to filled pot weight) for all pots by manual watering through irrigation spikes (Products of Excellence Pty Ltd, Brookvale, NSW, Australia) placed in the middle of each pot. 
Seedling emergence and the number of seedlings that survived to the end of the experiment were recorded for all pots. Plants were harvested at six months after sowing. Shoots were harvested by severing at about $0.5 \mathrm{~cm}$ above the soil surface, and lightly washed to remove any soil. Roots were retrieved by washing away the substrates under gently running water over a mesh grid $(2 \mathrm{~mm})$ to prevent loss of biomass. Roots were not harvested for treatment groups with poor survival, mainly in tailings and mix pots. Extra attention will be paid when interpreting the effect of plant growth on chemical changes of mined substrates. Harvested shoot and root mass was determined after drying the plant material to a constant weight at $70^{\circ} \mathrm{C}$ for at least 72 hours. Dry biomass is expressed on a per-pot basis.

\section{Soil analyses}

Soil samples of ca. $500 \mathrm{~g}$ were collected after plant biomass was harvested, and sieved to remove large debris, roots and small gravel ( $2 \mathrm{~mm}$ stainless steel sieve) before being stored in zip-lock polyethylene bags at $4^{\circ} \mathrm{C}$ for up to one week prior to analysis of microbial biomass and mineral $\mathrm{N}$ measurements. For each sample, about $250 \mathrm{~g}$ subsamples were air-dried $\left(35^{\circ} \mathrm{C}\right.$ for up to one week) and stored in zip-lock polyethylene bags at room temperature for analysis of other chemical properties.

Soil microbial biomass carbon (MBC) and nitrogen (MBN) was measured by $\mathrm{CHCl}_{3}$ fumigation and $0.5 \mathrm{M}$ $\mathrm{K}_{2} \mathrm{SO}_{4}$ extraction of fresh soil as described in Vance et al. (1987) and Brookes et al. (1985). Soluble organic carbon (C) in extracts was analysed using an Aurora 0.I 1030W wet oxidation total organic carbon analyser (College Station, Brazos, TX, USA). A conversion factor $(\mathrm{Kc})$ of 0.45 was applied to the MBC results as described in Wu et al. (1990). A conversion factor $(\mathrm{K} n)$ of 0.54 was applied to the MBN results as described in Brookes et al. (1985). Soil microbial biomass $\mathrm{P}$ (MBP) was measured by $\mathrm{CHCl}_{3}$ fumigation and $0.5 \mathrm{M} \mathrm{NaHCO}_{3}$ extraction of fresh soil, as described in Brookes et al. (1982). Phosphorus concentrations were determined colorimetrically using a UV160A spectrophotometer at $880 \mathrm{~nm}$ (Shimadzu, Kyoto, Japan) after reaction with molybdate blue (Murphy and Riley 1962; Blakemore et al. 1987). A conversion factor (Kp) of 0.4 was applied to the MBP results as described in Brookes et al. (1982). Soil mineral $\mathrm{N}\left(\mathrm{NH}_{4}-\mathrm{N}\right.$ and $\left.\mathrm{NO}_{3}-\mathrm{N}\right)$ was extracted with $2 \mathrm{M} \mathrm{KCl}$ from fresh soil (Clough et al. 2001), and determined by LACHAT FIA QuikChem 8500 Series 2 (Loveland, CO, USA).

Soil pH (both in DI water and in $0.01 \mathrm{M} \mathrm{CaCl}_{2}$ ) and electrical conductivity (EC) (deionised water) were measured for each sample using soil $\mathrm{pH}$ and $\mathrm{EC}$ probes calibrated with $\mathrm{pH} 4$ and 7 buffer solutions (Orion 720a, Beverly, MA, USA). Soil total organic matter content was determined by the loss on ignition (LOI) method. Air-dried soil was dried in a crucible at $105^{\circ} \mathrm{C}$ in an oven for 12 hours, re-weighed when cool, placed in a muffle furnace, held at $500^{\circ} \mathrm{C}$ for four hours, and then re-weighed when cool. Soil organic $\mathrm{C}$ concentration was estimated by dividing the total organic matter (measured as LOI) by 1.72 (Blakemore et al., 1987). Total $\mathrm{N}$ was measured by the combustion method via a Leco analyser (FP628, St. Joseph, MI, USA).

Exchangeable cations were determined by extraction in $0.1 \mathrm{M} \mathrm{BaCl}_{2}(2 \mathrm{~h}, 1: 30$ soil-to-solution ratio), with detection by inductively coupled plasma optical-emission spectrometry (ICP-OES) (Thermo iCAP 6000 
series ICP-OES, Freemont, CA, USA) following the methods of Blakemore et al. (1987). Effective cation exchange capacity (ECEC) was calculated as the sum of $\mathrm{Al}, \mathrm{Ca}, \mathrm{K}, \mathrm{Mg}$ and $\mathrm{Na}$ concentrations. Colwell-P and -potassium ( $\mathrm{K}$ ) were extracted with $0.5 \mathrm{M} \mathrm{NaHCO}_{3}$ (adjusted to $\mathrm{pH}=8.5$ ) from air-dried soil (16 $\mathrm{h}$, 1:40 soil-to-solution ratio). Phosphorus and $K$ concentrations ( $[\mathrm{P}]$ and $[\mathrm{K}])$ in the extracts were determined colorimetrically (Rayment and Lyons 2010), using a UV160A spectrophotometer at $880 \mathrm{~nm}$ (Shimadzu, Kyoto, Japan) and atomic absorption spectroscopy (Varian SpectrAA 55A AAS, Palo Alto, CA, USA), respectively.

All soil data are presented as changes per total biomass using the difference of treated pots between unplanted controls divided by total dry biomass per pot.

\section{Statistical analyses}

Three-way analysis of variance (ANOVA) with plant species, inoculation, substrates, and the interaction of them included as fixed effects were used to test for the effects of species, inoculation, and substrate types on soil parameter changes per total biomass. This was followed by a nonparametric analysis (Wilcoxon test) by substrates to test the concatenated effects of plant species and inoculation on soil parameters. Student's $t$ tests were conducted between inoculated and non-inoculated plant biomasses within substrate type according to the data sets' distribution normality and variance homogeneity. For each species, the differences in plant biomass produced in different substrates were not tested statistically because some species had less than three surviving individuals in tailings or capped tailings; also the greatest plant biomass was produced in the stockpiled topsoil. Data and statistical analyses were performed using JMP® 15 (SAS Institute Inc., Cary, NC, USA). All model results are summarised in Tables S2 and S3 in the Supplementary Materials.

\section{Results}

\section{Plant growth}

While plant growth varied greatly among species, we observed a clear pattern that plants grown in stockpiled topsoil grew better than those that grew in capped tailings and tailings (Table 1). Regardless of inoculant application, all plant species had the highest survivorship and produced the greatest biomass in stockpiled topsoil, followed by capped tailings. Tailings clearly limited plant growth and produced the smallest biomass for all species. Specifically, when we analysed the effect of microbial inoculant, significantly more biomass was produced by E. loxophleba $(p=0.003), H$. recurva $(p=0.110)$ and $M$. georgei $(p=0.001)$ with inoculation in stockpiled topsoil than on the same substrate without inoculation. However, inoculation tended to be less effective in the capped tailings as no statistically significant difference was observed in biomass produced for any species, apart from M. georgei $(p<$ 0.001). Hakea recurva even produced slightly more biomass in non-inoculated capped tailings than in inoculated pots $(p=0.170)$. Mixing stockpiled topsoil into the surface of tailings (without inoculation) had a minor effect on improving plant growth as plant roots mostly grew in the topsoil-mixed layer. Due to insufficient numbers of surviving plants, statistical analysis was not conducted for plants in tailings 
pots, but the produced biomass tended to be marginally greater in inoculated pots. There were no root nodules (fresh or dead) found on the putatively $\mathrm{N}$-fixing species, Acacia ramulosa and Allocasuarina acutivalvis, on any of the substrates and treatments.

Table 1

Plant biomass harvested after six months of growth and results of Student's $t$ test comparing inoculated and non-inoculated plants within substrate type. Data are mean values with standard error in parentheses, $n=3-5$; species with less than three surviving samples do not have standard error but are marked with dashes.

\begin{tabular}{|c|c|c|c|c|c|}
\hline \multirow[b]{3}{*}{ Species } & \multirow[b]{3}{*}{ Substrate } & \multicolumn{4}{|c|}{ Total biomass (g) } \\
\hline & & \multicolumn{2}{|l|}{ Treatment } & \multicolumn{2}{|c|}{ Statistics } \\
\hline & & Inoculated & Non-inoculated & $t$ & $p$ \\
\hline \multirow[t]{3}{*}{ Acacia ramulosa } & Topsoil & $5.68(1.67)$ & $2.72(1.01)$ & -1.511 & 0.177 \\
\hline & Capped tailings & $1.25(0.30)$ & $0.65(0.12)$ & -1.822 & 0.125 \\
\hline & Tailings & $0.32(0.18)$ & $0.07(0.04)$ & - & - \\
\hline \multirow[t]{3}{*}{ Allocasuarina acutivalvis } & Topsoil & $4.33(0.63)$ & $3.19(0.59)$ & -1.316 & 0.225 \\
\hline & Capped tailings & $0.84(0.19)$ & $0.58(0.09)$ & -1.19 & 0.278 \\
\hline & Tailings & $0.29(0.15)$ & $0.35(0.26)$ & - & - \\
\hline \multirow[t]{3}{*}{ Austrostipa scabra } & Topsoil & $3.40(0.19)$ & $2.43(0.57)$ & -1.620 & 0.167 \\
\hline & Capped tailings & $3.07(0.28)$ & $0.10(-)$ & - & - \\
\hline & Tailings & $0.16(0.05)$ & $0.01(-)$ & - & - \\
\hline \multirow[t]{3}{*}{ Eucalyptus loxophleba } & Topsoil & $8.53(1.15)$ & $2.45(0.88)$ & -4.203 & 0.003 \\
\hline & Capped tailings & $2.53(0.43)$ & $0.25(-)$ & - & - \\
\hline & Tailings & $0.09(-)$ & $0.01(-)$ & - & - \\
\hline \multirow{3}{*}{$\begin{array}{l}\text { Hakea } \\
\text { recurva }\end{array}$} & Topsoil & $5.92(0.54)$ & $4.58(0.51)$ & -1.796 & 0.110 \\
\hline & Capped tailings & $1.71(0.21)$ & $2.48(0.44)$ & 1.570 & 0.170 \\
\hline & Tailings & $1.59(0.33)$ & $0.85(-)$ & - & - \\
\hline \multirow[t]{3}{*}{ Maireana georgei } & Topsoil & $10.99(0.56)$ & $6.82(0.38)$ & -6.182 & 0.001 \\
\hline & Capped tailings & $2.39(0.13)$ & $0.05(0.01)$ & -17.590 & $<0.001$ \\
\hline & Tailings & $0.57(0.19)$ & $0.08(-)$ & - & - \\
\hline
\end{tabular}

\section{Changes in soil biological and chemical properties}


In general, the chemical properties of stockpiled topsoil (per total biomass produced) showed relatively minor changes in response to plant species and microbial inoculation, compared with capped tailings and tailings. Despite the overall patterns, changes of soil $\mathrm{pH}$, organic $\mathrm{C}$, total $\mathrm{N}$, and cation exchange capacity per total biomass were not significant in stockpiled topsoil across all plant species (Figs. 1, 2, 3 and 4). However, plants exhibited strong effects on the biological properties of stockpiled topsoil, as changes in microbial biomass $\mathrm{C}(p=0.0043)$ and $\mathrm{P}(p=0.011)$ per total biomass differed significantly among plant species in stockpiled topsoil pots, although less prominent for microbial biomass $\mathrm{N}(p=$ 0.0575 ) (Figs. 5, 6 and 7). Changes in soil microbial biomass $C, N$ and $P$ were mainly driven by the species and inoculation interactions (Table S2). No statistically significant differences were observed in changes of plant-available soil $\mathrm{P}$ (measured as Colwell P), EC, Colwell $\mathrm{K}$, and exchangeable $\mathrm{K}$ and $\mathrm{Na}$ in stockpiled topsoil pots (Figs S4, S5, S6, S10 and S11).

Capped tailings pots responded to a relatively minor degree to microbial inoculation (Table S3), and this was most evident in changes of substrate organic $\mathrm{C}$ and microbial biomasses per plant biomass (Figs. 2, 4, 5 and 6). However, due to the very low plant survival rate in pure tailings pots at the end of the glasshouse trial, only $M$. georgei without inoculation showed a significantly increase in microbial biomass $\mathrm{C}, \mathrm{N}$ and $\mathrm{P}$ in tailings ( $p=0.0003$ ) (Figs. 4, 5 and 6). Even though $A$. ramulosa, $A$. acutivalvis, $A$. scabra and E. loxophleba did not survive after six months in pure tailings, they led to some changes in soil $\mathrm{pH}$, organic $\mathrm{C}$, total $\mathrm{N}$, and effective cation exchange capacity.

Finally, three-way ANOVA indicated that the interaction of plant species and inoculation was an important factor contributing to changes in chemical and biological characteristics per total biomass in different substrates, apart from $\mathrm{NH}_{4}-\mathrm{N}$, total $\mathrm{N}$ and Colwell $\mathrm{P}$ (Table S2).

\section{Discussion}

Our results, first, highlight the importance of re-vegetating the stockpiled topsoil if direct transfer or shortterm storage of stripped natural topsoil is not feasible. Re-vegetation using local keystone species, including both legumes and non-legumes, can significantly improve the health of stockpiled topsoil. This will benefit future restoration of post-mining land. Second, the beneficial effect of adding a commercially available microbial inoculant, which is usually advertised to be effective in promoting plant growth, was not significant in the present study. Possible reasons might be the incompatibility between selected native plant species and the broad-spectrum commercial inoculant. This warrants further research in isolating and selecting locally sourced soil microbes to assist post-mining land restoration, which usually involves site-specific practices. Third, the potential alleviation of chemical properties of tailings as affected by plant growth was relatively limited and varied greatly among plant species. In particular, the non-mycorrhizal species $M$. georgei was very effective at improving the biological health of tailings (as reflected in larger microbial biomasses changes per plant biomass). Maireana georgei is also considered as a disturbance-specialist species (Nano and Clarke 2008). Our results have important implications for the management of stripped topsoil and restoration of post-mining landscapes. However, there are also limitations in terms of the transferability of results from our glasshouse experiments to restoration 
practitioners because plants in the field are exposed to multiple biotic and abiotic stresses, and varied conditions.

\section{Importance of re-vegetating stockpiled topsoil}

The impact of topsoil stockpiling is largely the loss of the biological integrity of the topsoil. This has been reported in native plant bioassay experiments using stockpiled topsoil of different ages, showing that stockpiling alters soil bacterial communities and reduces microbial diversity (Birnbaum et al. 2017; Gorzelak et al. 2020). This impact on native plant growth and physiological performance was further investigated by using stockpiled and natural topsoil across different ages (up to 29 years) and ecosystems (Valliere et al. 2021). The authors concluded that plants respond mostly to biological soil differences, instead of minor difference in soil physio-chemistry across mine sites. This was also particularly evident by the absence of successful nodulation in two putatively $\mathrm{N}$-fixing species in the stockpiled topsoil (both with and without commercial inoculant) in the present study. Clearly, long-term topsoil stockpiling had negative effect on soil N-fixing microbes. Gorzelak et al. (2020) found that one of the key rhizobial taxa, Bradyrhizobium, was gradually lost during long-term soil storage at a mine site. This is at odds with a previous suggestion that $\mathrm{N}$-fixing bacteria have better resilience to disturbance than other soil microorganisms (Jasper 2007). It is also worth noting that in the present study the chance of nitrate (up to $0.73 \mathrm{mM}$; Table S4) in the topsoil to suppress nodulation was low. Rawsthorne et al. (1985) suggested nitrate concentration greater than 1.4 - 3 mM suppress nodule formation in chickpea. It is also possible that the present Western Australian native $\mathrm{N}$-fixing species can function at low $\mathrm{N}$ supply and may not invest resources in biological $\mathrm{N}$ fixation (Pate et al. 1998). In the present study, the measured soil chemical properties remained mostly unchanged due to plant growth, while, more importantly, we clearly demonstrated that soil microbial biomass properties can be significantly improved via re-vegetating the stockpiled topsoil with local keystone plant species, compared with unplanted control topsoil. Soil microbial biomass measurements estimate the living component and provide good indicators of soil biological health (Wardle 1998). Healthy soil microbial communities contribute to above- and belowground interactions, which will benefit the ecological restoration of mined lands (Kardol and Wardle 2010). Therefore, where feasible, it is recommended to at least re-vegetate topsoil stockpiles using keystone native species, including legumes and non-legumes, to restore and maintain biological functions of the soil which will facilitate future mine-site restoration.

\section{Effect of commercially-available microbial inoculant}

Known benefits of having healthy soil microorganisms in plant growth have driven studies in reconstructing soil microbial communities of degraded ecosystems. Unlike decades of application of soil microbial inoculants (for example plant growth-promoting rhizobacteria) in the agricultural sector (Chaparro et al. 2012; Vishwakarma et al. 2020), this practice is far less common and only recently explored in mine-site restoration. For instance, Moreira-Grez et al. (2019) aimed to recondition the microbial communities of stockpiled topsoil sourced from a mine site in an arid region via adding a commercially-available agricultural-based soil microbial inoculant. Wong et al. (2021) aimed to improve 
the performance of a crop species, pigeon pea (Cajanus cajan), on mined overburden material via adding a similar agricultural-based product. Similar to their results, we show limited benefits from inoculation with an agricultural-based microbial mixture. Possible reasons are the incompatibility between inoculated mixtures of exogenous microorganisms, local soil conditions and native plant species. More recently, indigenous cyanobacteria sourced from local biocrusts were investigated in terms of promoting plant emergence and growth for arid-region mine-site restoration in a mesocosm study (Chua et al. 2020) and restoring microbial communities of stockpiled topsoil (Jiménez-González et al. 2022); both showing promising results. Therefore, we recommend conducting further research testing the effectiveness of indigenous soil biota for mine-site restoration under different climatic conditions.

\section{Effects of plant nutrient-acquisition strategies}

Ecological restoration utilising plant functional trait-based approach has become increasingly popular (Carlucci et al. 2020), while studies specifically investigating the role of plant nutrient-acquisition strategies in ecological restoration have received little attention, in particular in the context of mine-site restoration. For example, plant-plant facilitation traits have been considered, such as canopy structure, resistance to soil erosion, water-use strategies, tolerance to environmental stressors, when screening for species for rehabilitating metalliferous tailings in a semi-arid region of Spain (Navarro-Cano et al. 2019) and specifically plant nutrient-acquisition strategies, such as mycorrhizal and non- mycorrhizal, in midwest Western Australia (Cross 2021). Mined overburden materials or processed tailings are often physically and chemically inhospitable to most plants due to non-soil like structure, extreme $\mathrm{pH}$, and low organic matter content and nutrient ( $\mathrm{N}$ and $\mathrm{P}$ ) availability (Cross et al. 2021b). In the present glasshouse experiment, the non-mycorrhizal disturbance-specialist $M$. georgei was effective (per unit total biomass) in improving the microbial biomass of tailings (without adding inoculant), while the arbuscular mycorrhizal or ectomycorrhizal E. loxophleba led to the greatest increase in organic $\mathrm{C}$ in tailings. The interactions between microbial inoculant and $\mathrm{N}$-fixing species $A$. ramulosa have driven the significant increases in microbial biomass $\mathrm{C}, \mathrm{N}$ and $\mathrm{P}$. However, the interpretation of these changes needs to be done with great care because the changes might be associated with very little biomass (less than $1 \mathrm{~g}$ ) used in the calculation. The $\mathrm{N}$ concentration was not increased in tailings by two putatively $\mathrm{N}$-fixing species, $A$. ramulosa and $A$. acutivalvis, because their symbiotic microbes were most likely absent in tailings. This warrants future research about rhizobia (exogenous or indigenous) and testing their efficacies with local $\mathrm{N}$-fixing species on targeted mined substrates. Cross et al. (2021a) tested the performance of 40 local plant species and found that $\mathrm{N}$-fixing species and cluster-root forming P-mobilising species from a calcicole group grew better than species without specialised nutrient-acquisition strategies from a calcifuge group on magnetite tailings. Recently, we used narrow-leaf lupin (Lupinus angustifolius), capable of fixing $\mathrm{N}$ and mobilising $\mathrm{P}$ (releasing carboxylates without cluster-root formation), as a model eco-engineering plant to ameliorate magnetite tailings for subsequent growth of native species (Zhong et al. 2021). In this case, an equivalent eco-engineering native plant species would be an ideal candidate to test. If unavailable, selecting local plant species with complementary traits, such as mixed culture of $\mathrm{N}$ fixing and P-mobilising species, would potentially promote the establishment of pioneer vegetation on hostile mined substrates. These warrant further studies. 


\section{Concluding Remarks}

This study, first, highlights that the management of topsoil stockpiles deserves more attention, with explicit consideration of restoring the soil biological integrity, which is important for the success of postmining restoration. Second, commercially-sourced agricultural-based microbial inoculants are unlikely to be effective in the context of mine-site restoration; therefore, future studies might explore the use of indigenous soil biota. Finally, where mixed cultures are possible, we recommend selecting local plant species with facilitating interactions, including disturbance-specialists and species with complementary nutrient-acquisition strategies, in post-mining restoration under a variety of environmental and edaphic stressors.

\section{Declarations}

\section{Acknowledgement}

The authors thank Michael Smirk for help in the ICP-OES analysis and Michael Blair for help in the use of glasshouse facilities. The authors thank Jean W.H Yong, Feng Wang, Jingwen Gao, and Yingyuan Shi for the help in setting up the experiment.

\section{Funding}

This research was supported by the Australian Government through the Australian Research Council Industrial Transformation Training Centre for Mine Site Restoration (Project Number ICl150100041) and Australian Research Council Linkage project (LP160100598). ATC was supported by the Research Fellowship in Restoration Ecology jointly funded by the EcoHealth Network, Gelganyem Limited, and Curtin University. HL received support from the Deputy Vice Chancellor (Research) at the University of Western Australia.

\section{Author information}

\section{Affiliations}

School of Biological Sciences, The University of Western Australia, 35 Stirling Highway, Perth, WA 6009, Australia

Hongtao Zhong, Wei San Wong \& Hans Lambers

Centre for Mine Site Restoration, School of Molecular and Life Sciences, Curtin University, Kent Street, Bentley, WA 6102, Australia 
Hongtao Zhong, Wei San Wong \& Hans Lambers

Key Laboratory of Mountain Surface Processes and Ecological Regulation, Institute of Mountain Hazards and Environment, Chinese Academy of Sciences, Chengdu 610041, China

Jun Zhou

EcoHealth Network, 1330 Beacon St, Suite 355a, Brookline, MA 02446, United States.

Adam T. Cross

School of Molecular and Life Sciences, Curtin University, GPO Box U1987, Bentley, WA 6102, Australia Adam T. Cross

\section{Contributions}

$H Z$, WW, AC, and $\mathrm{HL}$ planned and designed the experiment; $\mathrm{HZ}$, WW, and JZ performed the glasshouse experiment and soil analyses; HZ, WW, and JZ analysed and interpreted the data; and HZ, WW, JZ, AC, and $\mathrm{HL}$ wrote the manuscript. All authors contributed critically to the drafts and gave final approval for publication.

\section{Corresponding author}

Correspondence to Hongtao Zhong and Jun Zhou

\section{Ethics declarations}

\section{Conflict of interest}

We have no conflicts of interest to report. The industry partner that supported this research was only involved in facilitating mined substrates collection.

\section{References}

1. Aznar-Sánchez JA, Velasco-Muñoz JF, Belmonte-Ureña LJ, Manzano-Agugliaro F (2019) Innovation and technology for sustainable mining activity: A worldwide research assessment. J Clean Prod 221:38-54. https://doi.org/10.1016/J.JCLEPRO.2019.02.243

2. Beard JS (1990) Plant life of Western Australia. Kangaroo Press, Kenthurst [N.S.W] 
3. Birnbaum C, Bradshaw LE, Ruthrof KX, Fontaine JB (2017) Topsoil stockpiling in restoration: impact of storage time on plant growth and symbiotic soil biota. Ecol Restor 35:237-245. https://doi.org/10.3368/ER.35.3.237

4. Blakemore LC, Searle PL, Daly BK (1987) Methods for chemical analysis of soils (Rev. ed.). NZ Soil Bureau, Department of Scientific and Industrial Research, Lower Hutt, N.Z

5. Brookes PC, Landman A, Pruden G, Jenkinson DS (1985) Chloroform fumigation and the release of soil nitrogen: A rapid direct extraction method to measure microbial biomass nitrogen in soil. Soil Biol Biochem 17:837-842. https://doi.org/10.1016/0038-0717(85)90144-0

6. Brookes PC, Powlson DS, Jenkinson DS (1982) Measurement of microbial biomass phosphorus in soil. Soil Biol Biochem 14:319-329. https://doi.org/10.1016/0038-0717(82)90001-3

7. Carlucci MB, Brancalion PHS, Rodrigues RR et al (2020) Functional traits and ecosystem services in ecological restoration. Restor Ecol 28:1372-1383. https://doi.org/10.1111/REC.13279

8. Chaparro JM, Sheflin AM, Manter DK, Vivanco JM (2012) Manipulating the soil microbiome to increase soil health and plant fertility. Biol Fertil Soils 2012485 48:489-499. https://doi.org/10.1007/S00374-012-0691-4

9. Chua M, Erickson TE, Merritt DJ et al (2020) Bio-priming seeds with cyanobacteria: effects on native plant growth and soil properties. Restor Ecol 28:S168-S176. https://doi.org/10.1111/REC.13040

10. Clough TJ, Stevens RJ, Laughlin RJ et al (2001) Transformations of inorganic-N in soil leachate under differing storage conditions. Soil Biol Biochem 33:1473-1480. https://doi.org/10.1016/S0038-0717(01)00056-6

11. Cross AT (2021) Nutrient-acquisition strategy influences seed nutrient concentration and seed-toseedling transition in ecological restoration in a regional dryland flora. Plant Soil 2021 1-16. https://doi.org/10.1007/S11104-021-05198-Z

12. Cross AT, Ivanov D, Stevens JC et al (2021a) Nitrogen limitation and calcifuge plant strategies constrain the establishment of native vegetation on magnetite mine tailings. Plant Soil 461:181201. https://doi.org/10.1007/s11104-019-04021-0

13. Cross AT, Stevens JC, Sadler R et al (2021b) Compromised root development constrains the establishment potential of native plants in unamended alkaline post-mining substrates. Plant Soil 461:163-179. https://doi.org/10.1007/s11104-018-3876-2

14. Erickson TE, Muñoz-Rojas M, Kildisheva OA et al (2017) Benefits of adopting seed-based technologies for rehabilitation in the mining sector: a Pilbara perspective. Aust J Bot 65:646-660. https://doi.org/10.1071/BT17154

15. Fowler WM, Fontaine JB, Enright NJ, Veber WP (2015) Evaluating restoration potential of transferred topsoil. Appl Veg Sci 18:379-390. https://doi.org/10.1111/AVSC.12162

16. Ghose MK (2001) Management of topsoil for geo-environmental reclamation of coal mining areas. Environ Geol 20014011 40:1405-1410. https://doi.org/10.1007/S002540100321

17. Gibson N, Meissner R, Markey AS, Thompson WA (2012) Patterns of plant diversity in ironstone ranges in arid south western Australia. J Arid Environ 77:25-31. 
https://doi.org/10.1016/j.jaridenv.2011.08.021

18. Gorzelak M, McAmmond BM, van Hamme JD et al (2020) Soil microbial communities in long-term soil storage for sand mine reclamation. Ecol Restor 38:13-23. https://doi.org/10.3368/ER.38.1.13

19. Hart MM, Antunes PM, Abbott LK (2017) Unknown risks to soil biodiversity from commercial fungal inoculants. Nat Ecol Evol 201714 1:1-1. https://doi.org/10.1038/s41559-017-0115

20. Hart MM, Cross AT, D'Agui HM et al (2020) Examining assumptions of soil microbial ecology in the monitoring of ecological restoration. Ecol Solut Evid 1:e12031. https://doi.org/10.1002/26888319.12031

21. Huang L, Baumgartl T, Mulligan D (2012) Is rhizosphere remediation sufficient for sustainable revegetation of mine tailings? Ann Bot 110:223-238. https://doi.org/10.1093/aob/mcs115

22. Jasper DA (2007) Beneficial soil microorganisms of the Jarrah forest and their recovery in bauxite mine restoration in Southwestern Australia. Restor Ecol 15:S74-S84. https://doi.org/10.1111/J.1526-100X.2007.00295.X

23. Jiménez-González MA, Machado de Lima N, Chilton AM et al (2022) Biocrust cyanobacteria inoculants biomineralize gypsum and preserve indigenous bacterial communities in dryland topsoil. Geoderma 406:115527. https://doi.org/10.1016/J.GEODERMA.2021.115527

24. Kardol P, Wardle DA (2010) How understanding aboveground-belowground linkages can assist restoration ecology. Trends Ecol Evol 25:670-679.

https://doi.org/https://doi.org/10.1016/j.tree.2010.09.001

25. Kumaresan D, Cross AT, Moreira-Grez B et al (2017) Microbial functional capacity is preserved within engineered soil formulations used in mine site restoration. Sci Reports 2017 71 7:1-9. https://doi.org/10.1038/s41598-017-00650-6

26. Lambers H (2022) Phosphorus Acquisition and Utilization in Plants. Annu Rev Plant Biol 73:. https://doi.org/101146/annurev-arplant-102720-125738

27. Larney FJ, Angers DA (2012) The role of organic amendments in soil reclamation: A review. Can J Soil Sci 92:19-38. https://doi.org/10.4141/cjss2010-064

28. Markey AS, Dillon DJ (2008) Flora and vegetation ofthe banded iron formations of the Yilgarn Craton: central Tallering Land System. Conserv Sci West Aust 7:121-149

29. Marrs RH, Bradshaw AD (1993) Primary succession on man-made wastes: the importance of resource acquisition. In: Miles J, Walton DWH (eds) Primary Succession on Land. Blackwell Scientific Publications, Oxford; Boston, pp 113-136

30. Merino-Martín L, Commander L, Mao Z et al (2017) Overcoming topsoil deficits in restoration of semiarid lands: Designing hydrologically favourable soil covers for seedling emergence. Ecol Eng 105:102-117. https://doi.org/10.1016/J.ECOLENG.2017.04.033

31. Moreira-Grez B, Muñoz-Rojas M, Kariman K et al (2019) Reconditioning degraded mine site soils with exogenous soil microbes: Plant fitness and soil microbiome outcomes. Front Microbiol 10:1617. https://doi.org/10.3389/FMICB.2019.01617/BIBTEX 
32. Murphy J, Riley JP (1962) A modified single solution method for the determination of phosphate in natural waters. Anal Chim Acta 27:31-36. https://doi.org/10.1016/S0003-2670(00)88444-5

33. Nano CEM, Clarke PJ (2008) Variegated desert vegetation: Covariation of edaphic and fire variables provides a framework for understanding mulga-spinifex coexistence. Austral Ecol 33:848-862. https://doi.org/10.1111/J.1442-9993.2008.01855.X

34. Navarro-Cano JA, Goberna M, Verdú M (2019) Using plant functional distances to select species for restoration of mining sites. J Appl Ecol 56:2353-2362. https://doi.org/https://doi.org/10.1111/13652664.13453

35. Navarro-Cano JA, Verdú M, Goberna M (2018) Trait-based selection of nurse plants to restore ecosystem functions in mine tailings. J Appl Ecol 55:1195-1206.

https://doi.org/https://doi.org/10.1111/1365-2664.13094

36. Padda KP, Puri A, Chanway CP (2021) Long-term effects of inoculating lodgepole pine seedlings with plant growth-promoting bacteria originating from a disturbed gravel mining ecosystem. Can J For Res 51:533-545. https://doi.org/10.1139/CJFR-2020-0333/SUPPL_FILE/CJFR-20200333SUPPLA.PDF

37. Park JH, Edraki M, Mulligan D, Jang HS (2014) The application of coal combustion by-products in mine site rehabilitation. J Clean Prod 84:761-772.

https://doi.org/https://doi.org/10.1016/j.jclepro.2014.01.049

38. Pate JS, Unkovich MJ, Erskine PD, Stewart GR (1998) Australian mulga ecosystems ${ }^{-13} \mathrm{C}$ and ${ }^{15} \mathrm{~N}$ natural abundances of biota components and their ecophysiological significance. Plant Cell Environ 21:1231-1242. https://doi.org/10.1046/j.1365-3040.1998.00359.x

39. Perkins LB, Hatfield G (2016) Can commercial soil microbial treatments remediate plant-soil feedbacks to improve restoration seedling performance? Restor Ecol 24:194-201. https://doi.org/10.1111/REC.12302

40. Rawsthorne S, Hadley P, Summerfield RJ, Roberts EH (1985) Effects of supplemental nitrate and thermal regime on the nitrogen nutrition of chickpea (Cicer arietinum L.). Plant Soil 1985832 83:279-293. https://doi.org/10.1007/BF02184299

41. Rayment GE, Lyons DJ (2010) Soil Chemical Methods - Australasia. CSIRO Publishing, Collingwood, Vic

42. Roche C, Mudd G (2014) An overview of mining and the environment in Western Australia. In: Brueckner M, Durey A, Mayes R, Pforr C (eds) Resource Curse or Cure ?. CSR, Sustainability, Ethics \& Governance. Springer, Berlin, Heidelberg, pp 179-194

43. Santini TC, Banning NC (2016) Alkaline tailings as novel soil forming substrates: Reframing perspectives on mining and refining wastes. Hydrometallurgy 164:38-47. https://doi.org/https://doi.org/10.1016/j.hydromet.2016.04.011

44. Senior A, Britt A, Summerfield D et al (2021) Australia's Identified Mineral Resources 2020. Geoscience Australia, Canberra 
45. Singh JS, Pandey VC, Singh DP (2011) Efficient soil microorganisms: A new dimension for sustainable agriculture and environmental development. Agric Ecosyst Environ 140:339-353. https://doi.org/10.1016/J.AGEE.2011.01.017

46. Stevens J, Dixon K (2017) Is a science-policy nexus void leading to restoration failure in global mining? Environ Sci Policy 72:52-54. https://doi.org/10.1016/j.envsci.2017.01.006

47. Valliere JM, D'Agui HM, Dixon KW et al (2021) Stockpiling disrupts the biological integrity of topsoil for ecological restoration. https://doi.org/10.1007/S11104-021-05217-Z/FIGURES/6. Plant Soil 1-18

48. Vance ED, Brookes PC, Jenkinson DS (1987) An extraction method for measuring soil microbial biomass C. Soil Biol Biochem 19:703-707. https://doi.org/10.1016/0038-0717(87)90052-6

49. Vishwakarma K, Kumar N, Shandilya C et al (2020) Revisiting plant-microbe interactions and microbial consortia application for enhancing sustainable agriculture: A review. Front Microbiol 11:3195. https://doi.org/10.3389/FMICB.2020.560406/BIBTEX

50. Wardle DA (1998) Controls of temporal variability of the soil microbial biomass: A global-scale synthesis. Soil Biol Biochem 30:1627-1637. https://doi.org/10.1016/S0038-0717(97)00201-0

51. Wong WS, Morald TK, Whiteley AS et al (2021) Microbial inoculation to improve plant performance in mine waste substrates - a test using pigeon pea (Cajanus cajan). https://doi.org/10.1002/LDR.4165. L Degrad Dev

52. Wu J, Joergensen RG, Pommerening B et al (1990) Measurement of soil microbial biomass $C$ by fumigation-extraction-an automated procedure. Soil Biol Biochem 22:1167-1169. https://doi.org/10.1016/0038-0717(90)90046-3

53. Wu S, Liu Y, Southam G et al (2019) Geochemical and mineralogical constraints in iron ore tailings limit soil formation for direct phytostabilization. Sci Total Environ 651:192-202. https://doi.org/10.1016/j.scitotenv.2018.09.171

54. Zheng T, Liang C, Xie H et al (2019) Rhizosphere effects on soil microbial community structure and enzyme activity in a successional subtropical forest. FEMS Microbiol Ecol 95:fiz043. https://doi.org/10.1093/femsec/fiz043

55. Zhong H, Lambers $\mathrm{H}$, Wong WS et al (2021) Initiating pedogenesis of magnetite tailings using Lupinus angustifolius (narrow-leaf lupin) as an ecological engineer to promote native plant establishment. Sci Total Environ 788:147622. https://doi.org/10.1016/J.SCITOTENV.2021.147622

\section{Figures}




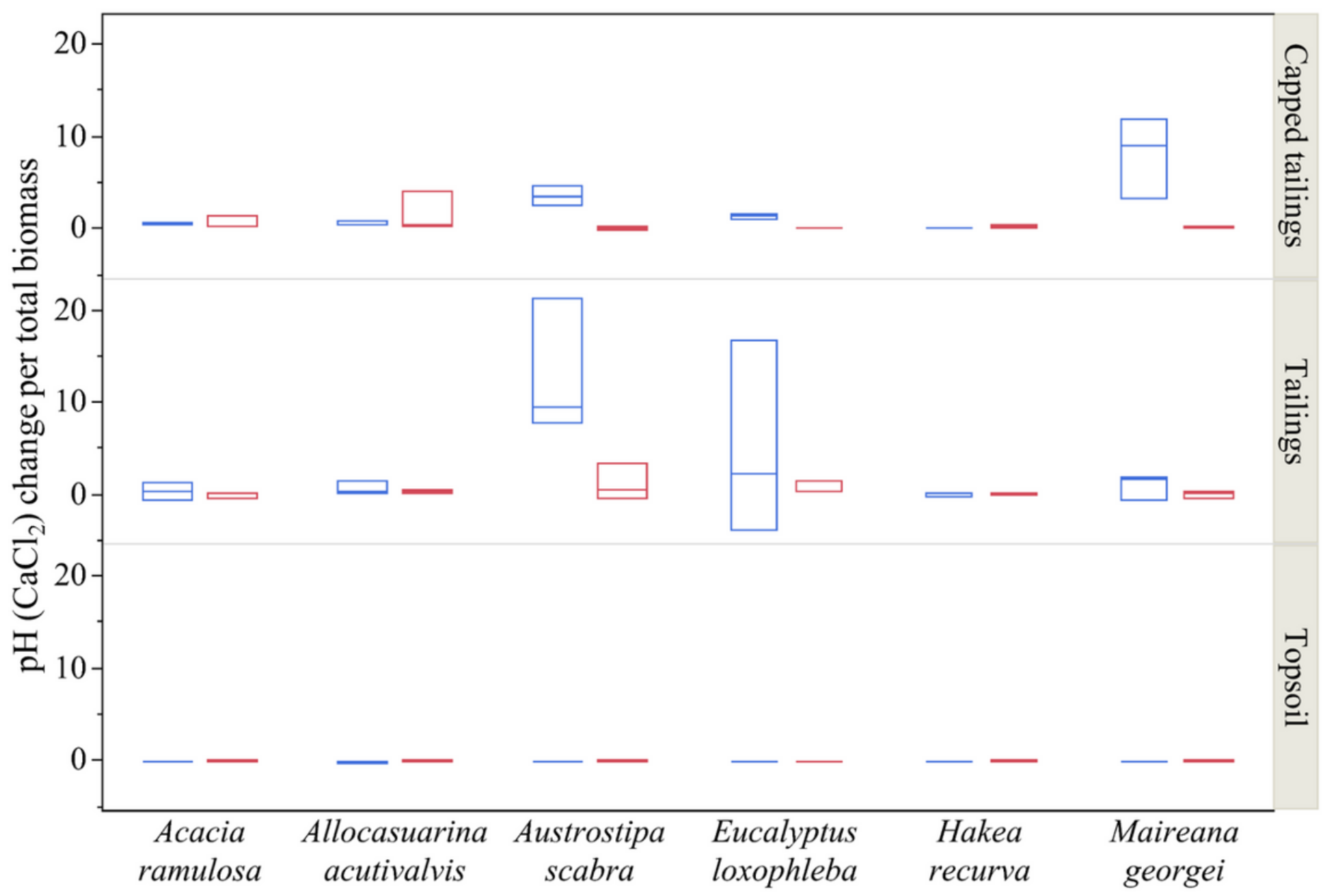

Figure 1

Changes in bulk substrate $\mathrm{pH}\left(\mathrm{CaCl}_{2}\right)$ per total biomass as affected by six selected species grown in three different substrates at the end of a glasshouse trial. Blue and red boxes refer to plant growth with and without addition of inoculant, respectively. Box plots are medians with $25^{\text {th }}$ and $75^{\text {th }}$ percentiles. 


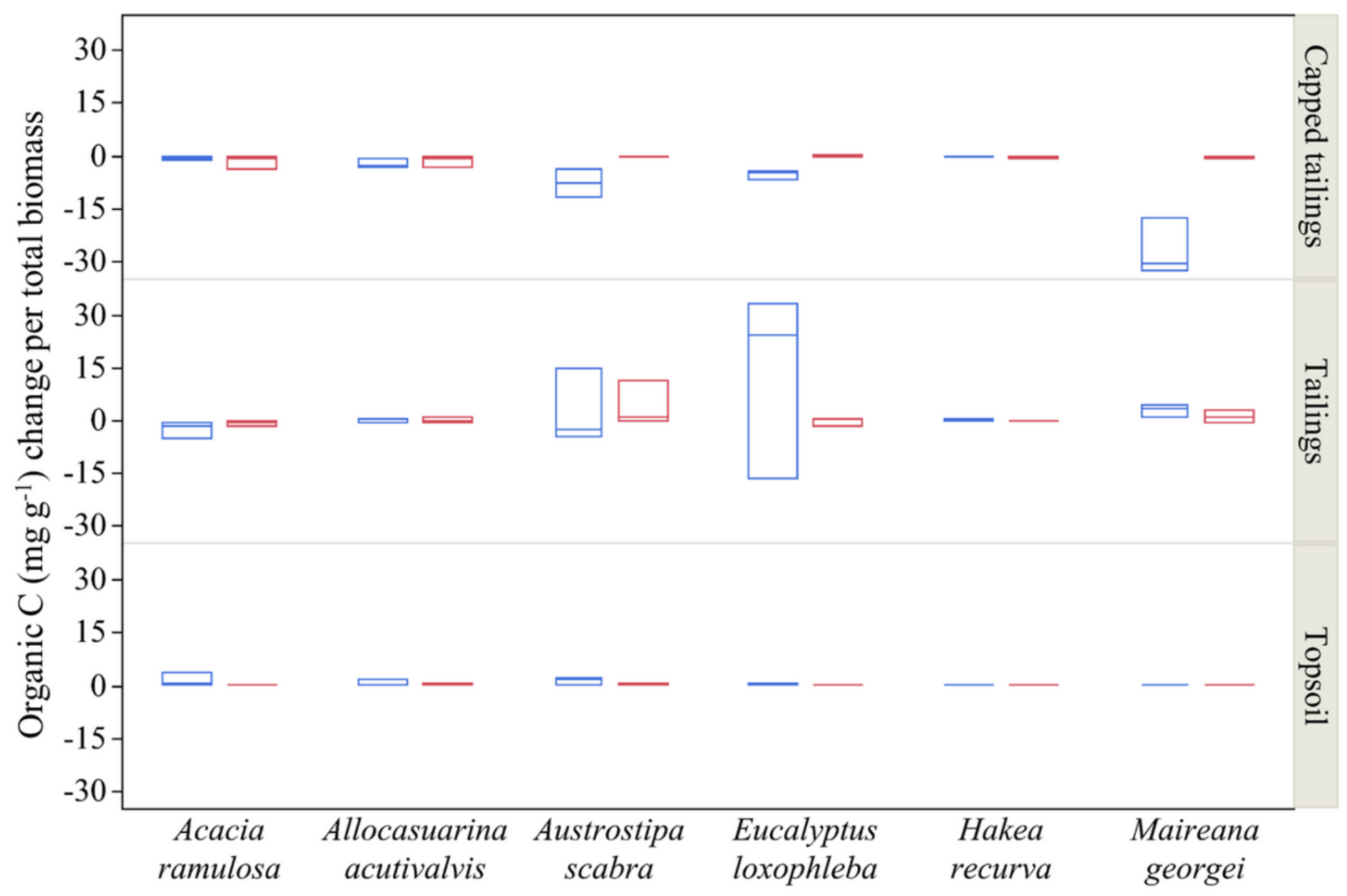

Figure 2

Changes in total organic carbon (C) in bulk substrate per total biomass as affected by six selected species grown in three different substrates at the end of a glasshouse trial. Blue and red boxes refer to plant growth with and without addition of inoculant, respectively. Box plots are medians with $25^{\text {th }}$ and $75^{\text {th }}$ percentiles. 


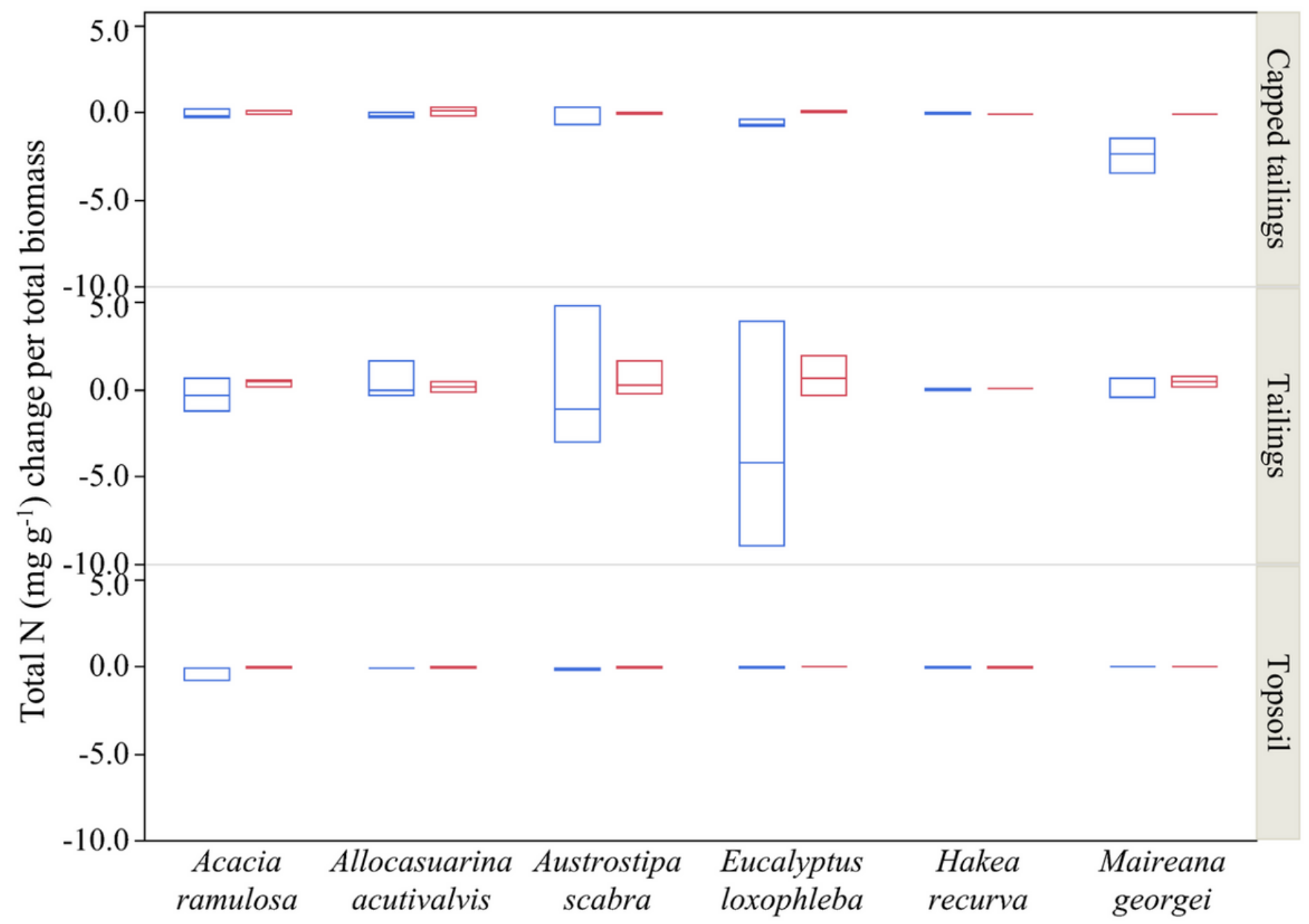

Figure 3

Changes in total nitrogen $(\mathrm{N})$ in bulk substrate per total biomass as affected by six selected species grown in three different substrates at the end of a glasshouse trial. Blue and red boxes refer to plant growth with and without addition of inoculant, respectively. Box plots are medians with $25^{\text {th }}$ and $75^{\text {th }}$ percentiles. 


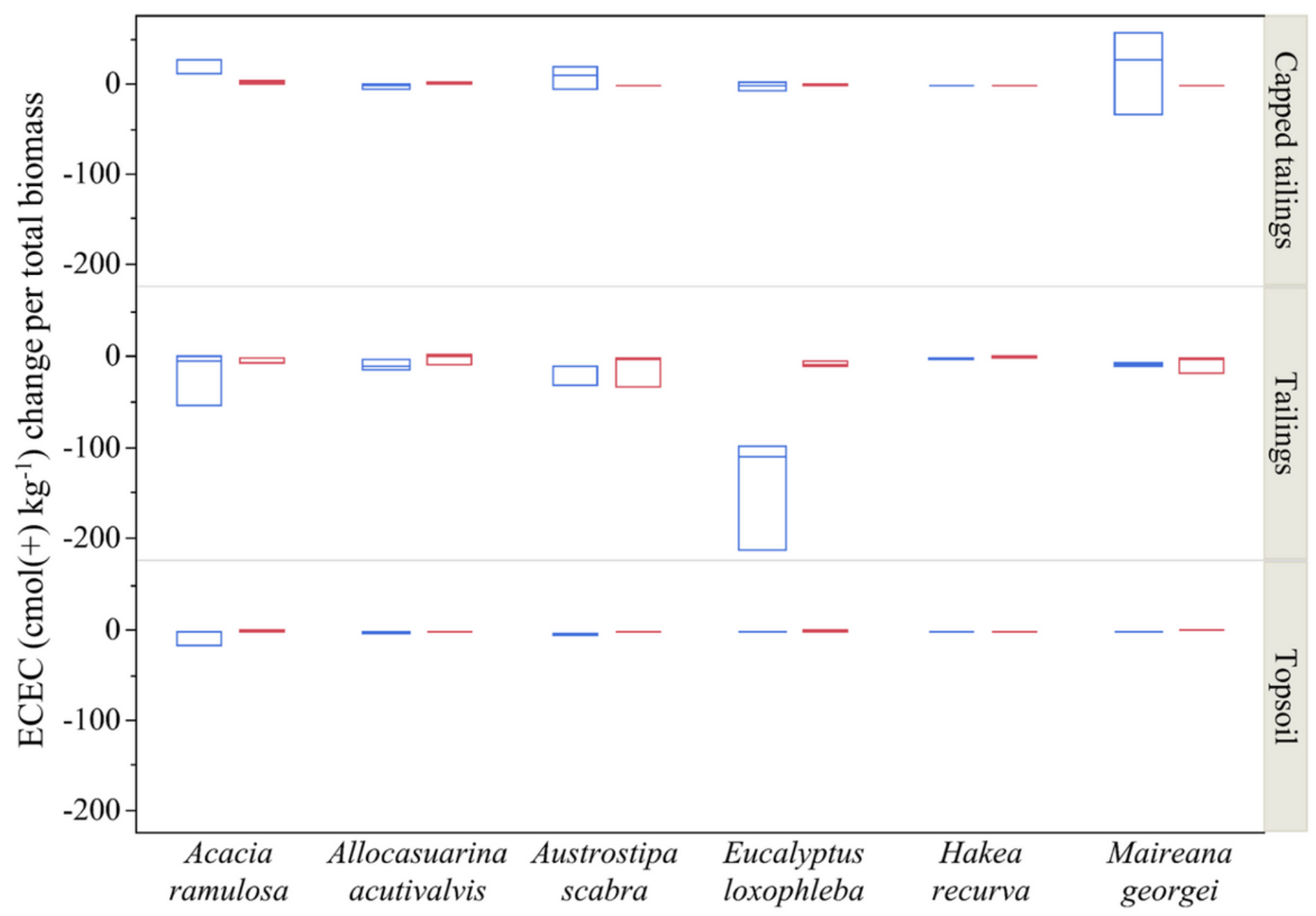

\section{Figure 4}

Changes in effective cation exchange capacity (ECEC) in bulk substrate per total biomass as affected by six selected species grown in three different substrates at the end of a glasshouse trial. Blue and red boxes refer to plant growth with and without addition of inoculant, respectively. Box plots are medians with $25^{\text {th }}$ and $75^{\text {th }}$ percentiles. 


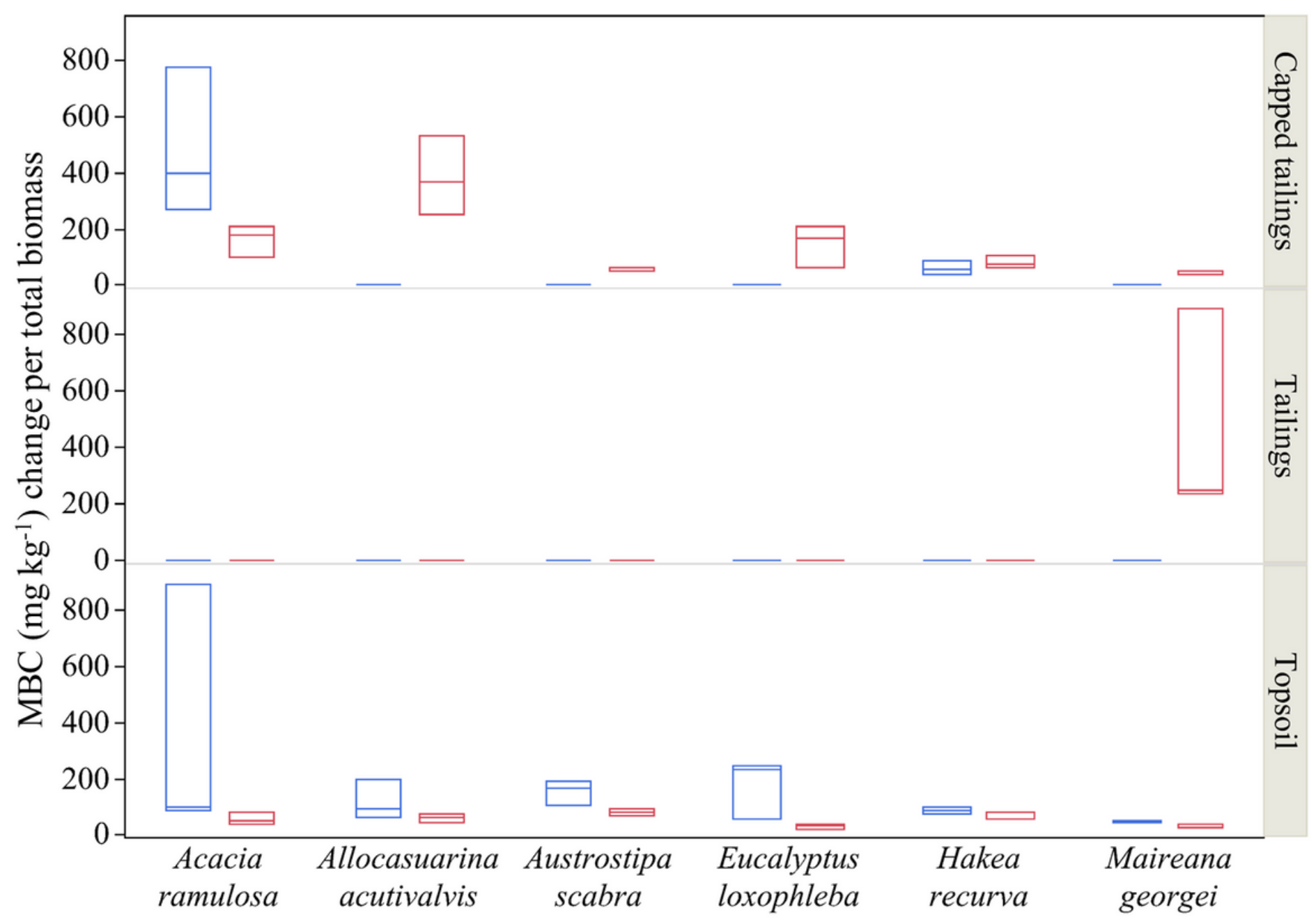

Figure 5

Changes in microbial biomass carbon (MBC) per total biomass in bulk substrate as affected by six selected species grown in three different substrates at the end of a glasshouse trial. Blue and red boxes refer to plant growth with and without addition of inoculant, respectively. Box plots are medians with $25^{\text {th }}$ and $75^{\text {th }}$ percentiles. 


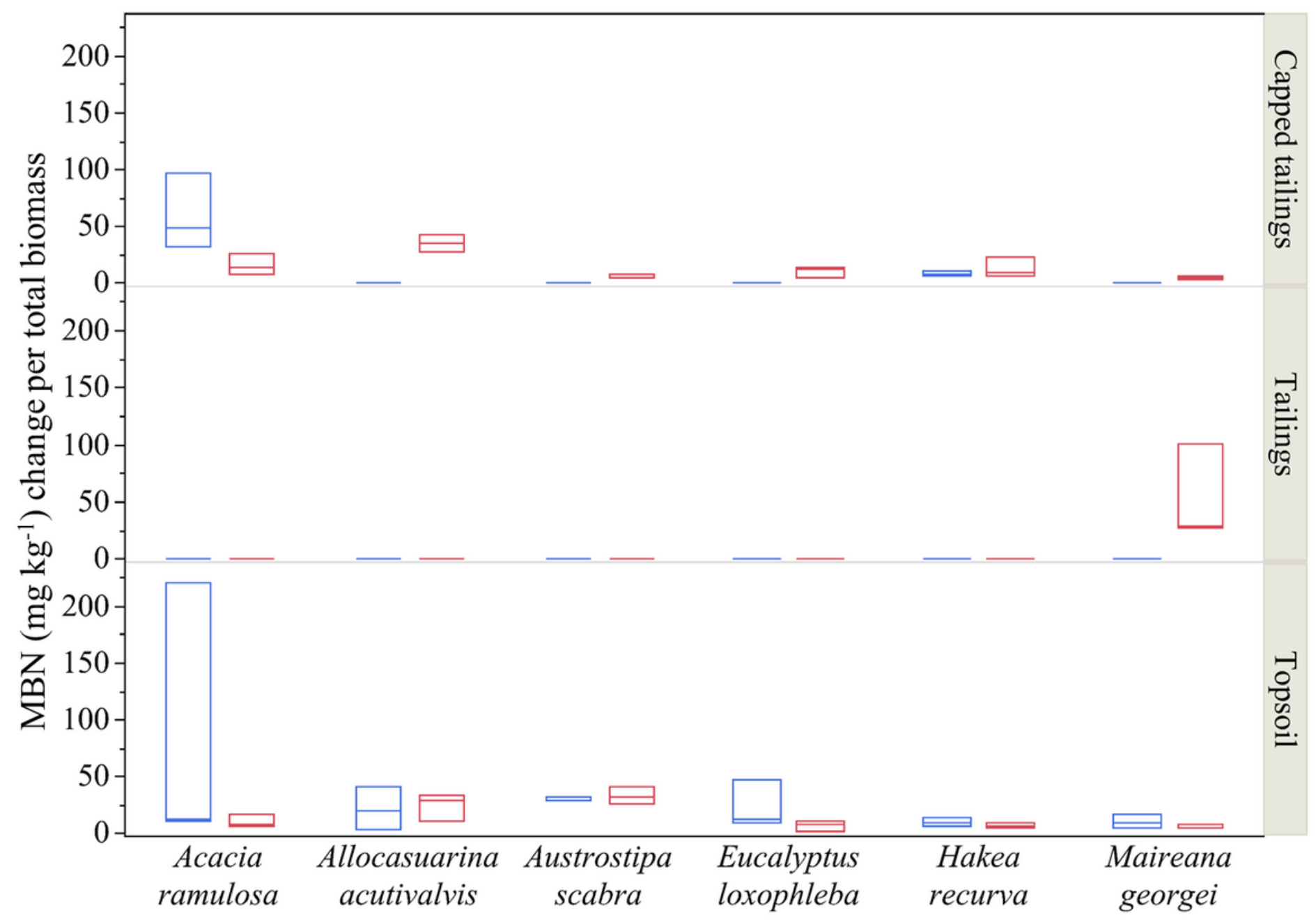

Figure 6

Changes in microbial biomass nitrogen (MBN) in bulk substrate per total biomass as affected by six selected species grown in three different substrates at the end of a glasshouse trial. Blue and red boxes refer to plant growth with and without addition of inoculant, respectively. Box plots are medians with $25^{\text {th }}$ and $75^{\text {th }}$ percentiles. 


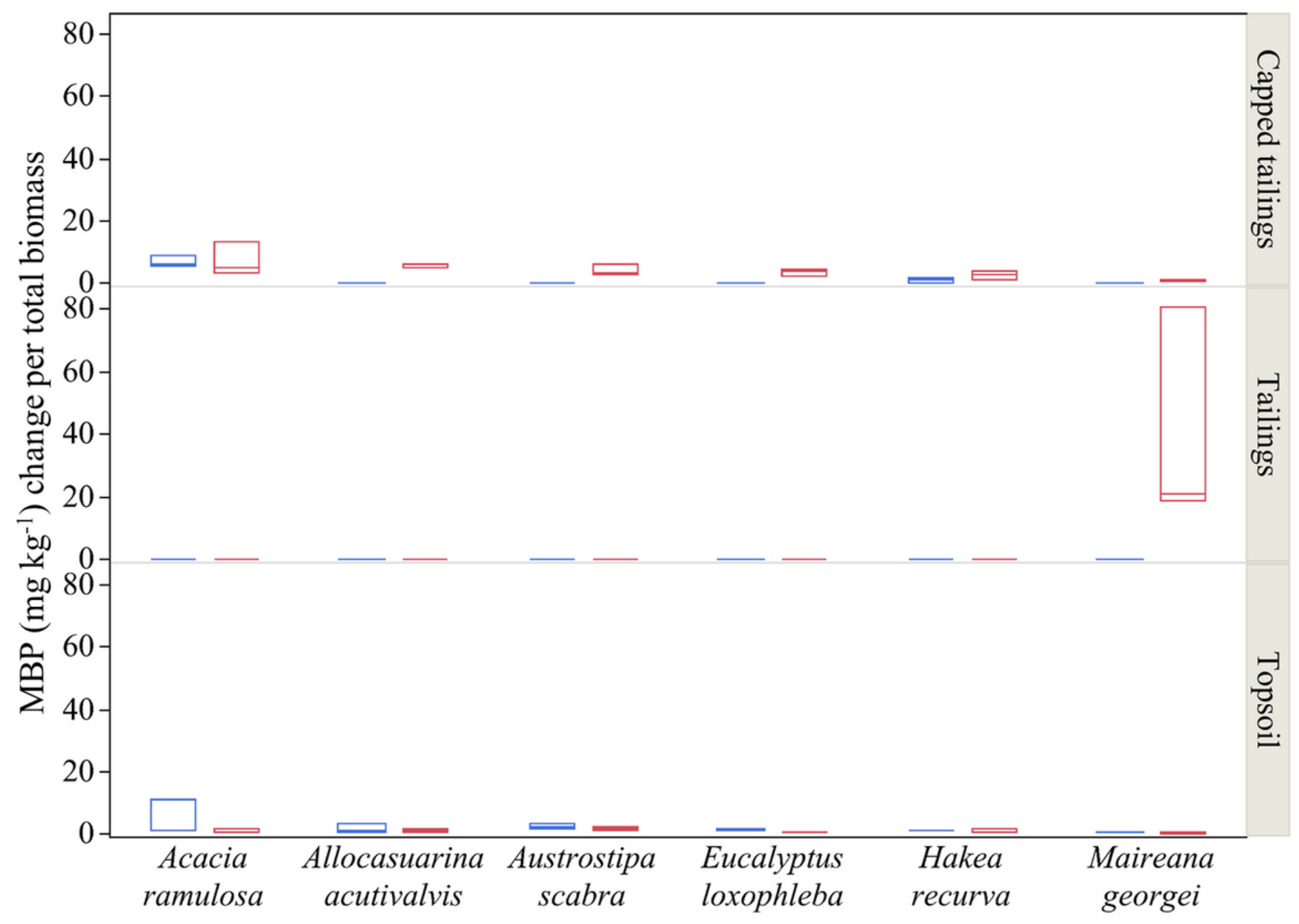

Figure 7

Changes in microbial biomass phosphorus (MBP) in bulk substrate per total biomass as affected by six selected species grown in three different substrates at the end of a glasshouse trial. Blue and red boxes refer to plant growth with and without addition of inoculant, respectively. Box plots are medians with $25^{\text {th }}$ and $75^{\text {th }}$ percentiles.

\section{Supplementary Files}

This is a list of supplementary files associated with this preprint. Click to download.

- SupplementaryInformation.docx 